\title{
ГІБРИДНІ АПАТИТ-БІОПОЛІМЕРНІ ПОКРИТТЯ, ОТРИМАНІ МЕТОДОМ ТЕРМІЧНОЇ ДЕПОЗИЦІї НА МОДЕЛЬНИХ ІМПЛАНТАТАХ 3 ТИТАНУ ТА ЙОГО СПЛАВІВ
}

\author{
Суходуб Л.Ф., \\ sukhodub@yahoo.com \\ доктор фіз.-мат.наук \\ професор, член-кор. НАН України \\ кафедра біофізики, біохімії, фармакології \\ та біомолекулярної інженерії, \\ Сумський державний університет \\ медичний інститут, \\ м.Суми, Україна
}

Peферат - Проблематика - розробка та виробництво покриттів для медичних імплантатів складають суттєвий сегмент сучасного ринку технологій. Враховуючи кількість хворих, яким потрібна операція по відновленню цілісності кісткової тканини, об'єми необхідних матеріалів оцінюються на рівні десятків тон.

Мета дослідження - аналіз стану розробок та технологій біоміметичного отримання багатофункціональних біосумісних наноструктурованих покриттів на основі ортофосфатів кальцію (CaP) та природних біополімерів хітозану (CS), альгінату (Alg), колагену $(\mathrm{Cg})$ у вигляді двофазних систем метал/покриття.

Методика реалізації - використання технології термічної депозиції (TSD-temperature substrate deposition) 3 водних розчинів прекурсорів.

Результати дослідження: В даному огляді просумовано наукові дані щодо методів отримання біоактивних, протимікробних СаР покриттів та дослідження їх властивостей. Відмічені особливості популярних технологій: плазмове розпилення, електрофоретичне та електрохімічне осадження, золь-гель, біоміметичне осадження. Зважаючи на підвищену резистентність мікроорганізмів до широкого ряду антибіотиків в останні десятиліття, в якості протимікробних засобів до складу покриттів були внесені альтернативні частинки неорганічного походження, а саме фулерен C60, наночастинки та іони срібла Agnano, Ag+, частинки цинку оксиду (ZnO). Сучасними інструментальними методами проведено аналіз структурних, фізичних та антибактеріальних властивостей покриттів. Висновки: Аналіз отриманих результатів щодо синтезу та структурно-фазових досліджень апатит-біополімерних покриттів, отриманих методом TSD в лабораторії «Біонанокомпозит» Сумського державного університету протягом останніх 5 років надає інформацію про стан досліджень за вказаною проблематикою та може бути корисним при подальших дослідженнях науковців, в тому числі молодих вчених.

Ключові слова: покриття, ортофосфати кальцію, біополімери, термодепозиція

\section{I. ВСТУП}

Розробка та виробництво покриттів, зокрема, на основі СаР для медичних імплантатів складають суттєвий сегмент ринку біоінженерних технологій. Подібна тенденція обумовлена тим, що лише незначна кількість матеріалів імплантатів $\epsilon$ толерантною до умов функціонування в живих організмах. Один із способів підняття ефективності функціонування медичних імплантатів в оточені біологічних рідин - це формування на їх поверхні біосумісних 3 оточуючими нативними структурами покриттів, заданого компонентного вмісту, зокрема, на основі СаР. Як показує аналіз літературних даних, біля 50 різновидів технологій осадження СаР покриттів було розроблено протягом останніх двох десятиліть 3 метою покращення властивостей поверхні металевих імплантатів [1]. Одним із методів $\epsilon$ технологія термічної депозиції на металевих субстратах (TSD, temperature substrate deposition,), яка базується на явищі залежності розчинності СаР від температури реакційного розчину. TSD методика - це технологія одноетапного осадження органічних та неорганічних компонентів на попередньо оброблену поверхню металевого субстрату, розігрітого пропусканням через нього електричного струму. Як було показано раніше [2-6], даний метод дозволяє одержувати гомогенні СаР покриття на Ti-6Al-4V субстратах 
при температурах $37-120^{\circ} \mathrm{C}$ i $\mathrm{pH} 6,5 \div 7,5$, морфологія та фазовий склад яких залежить від параметрів процесу. Температурний режим TSD технології осадження СаР на металеву основу дозволяє вводити до складу покриттів різні біомолекули, біоактивні частинки, а також лікарські засоби 3 метою надання покриттям додаткових біологічних та антибактеріальних властивостей. Модифікування поверхні субстратів хімічними та фізичними способами уможливлює вплив на кінетику утворення центрів кристалізації та ступінь кристалічності отриманих покриттів.

Метою даного огляду $є$ аналіз результатів, отриманих співробітниками лабораторії «Біонанокомпозит» Сумського державного університету за період 2015-2020рр. та деякими іншими авторами щодо $\mathrm{CaP}$ покриттів, нанесених методом TSD на поверхню модельних імплантів 3 титану та Ti-6Al-4V сплаву, 3 акцентом на гібридні апатитбіополімерні покриття. Результати досліджень до 2015 року наведені в наших ранніх оглядах $[6,7]$.

\section{II. МЕТОДИ ОТРИМАННЯ САР ПОКРИТТІВ НА МОДЕЛЬНИХ ІМПЛАНТАТАХ 3 ТИТАНУ ТА TI-6AL-4V СПЛАВУ}

Відомо, що більшість процесів осадження $\mathrm{CaP} \epsilon$ нерівноважними, а отримані осади відрізняються від прекурсорів. Тому склад осаджених покриттів, плівок та шарів не завжди обмежується фазовими діаграмами.

Зокрема, подібна ситуація $є$ характерною для так званих термічних технологій розпилення. Термічне розпилення відбувається за дуже високих температур $\left(\geq 1000^{\circ} \mathrm{C}\right)$, при цьому завжди відбувається підігрів субстрату осадженим гарячими краплями осаду. У деяких випадках це може призвести до фазового перетворення та перекристалізації поблизу зони розмежування «поверхня субстрату-осад». Тому для підтримання оптимальної температури підкладки необхідно застосовувати відповідний метод охолодження. Наприклад, при нанесенні покриття 3 НА за методом плазмового розпилення, НА у вигляді порошку подається в плазмовий струмінь. Частинки НА піддаються впливу дуже високих температур $\left(\sim 20000^{\circ} \mathrm{K}\right)$ протягом короткого часу $\left(\sim 10^{-3}-10^{-4} \mathrm{c}\right)$, при цьому більшість із них достатньо нагрівається, щоб стати розплавленими або принаймні пом'якшеними, що є важливим для їх адгезії до субстрату. Технології осадження парів можна розділити на дві основні групи: фізичне та хімічне осадження парів (PVD i CVD, відповідно). В той же час, методики PVD можуть бути додатково класифіковані в інший набір із двох груп: а) ті, що пов'язані 3 термічним випаровуванням, де матеріал нагрівається доти, доки його тиск у парах не стане більшим, ніж тиск оточення, і б) ті, що пов'язані 3 іонним розпиленням, де високоенергетичні пучки іонів та/або електронів бомбардують тверду мішень і вибивають атоми 3 ii поверхні. Зазвичай PVD відбувається у вакуумі, однак може бути здійснено у присутності деяких газів. Мішенню є вихідний матеріал, у нашому випадку - $\mathrm{CaP}$.

Магнетронне розпилення $є$ одним iз прикладів техніки PVD. Магнетрон - потужна вакуумна трубка, яка генерує мікрохвилі, використовуючи взаємодії потоку електронів із магнітним полем. На сьогодні магнетронне розпилення $€$ зручним стандартним методом осадження $\mathrm{CaP}$ на різні субстрати, а технологія $\epsilon$ комерційно доступною, наприклад, ВioComp Industries BV, Нідерланди. «Вологі» методи - це всі типи технік осадження 3 розчинів або суспензій як водних, так i неводних, які відбуваються за помірних температур $\left(\leq 100^{\circ} \mathrm{C}\right)$. Загалом процес осадження грунтується на гетерогенному явищі нуклеації, кінетика якого залежить від багатьох параметрів, таких як пересичення розчину, концентрація реагентів, температура, гідродинаміка, наявність або відсутність домішок, нуклеаторів, інгібіторів, тощо. Механізм осадження $\mathrm{CaP} 3$ водних розчинів, є досить складним, в першу чергу із-за їх метастабільності. Процеси осадження біологічних $\mathrm{CaP}$, таких як октакальцій фосфат (ОСР), кальцій дефіцитний гідроксиапатит (CDHA) і стехіометричний НА відбуваються через утворення однієї або декількох проміжних фаз та/або попередників, таких як аморфний кальцій фосфат (АCP), дикальцій фосфат дигідрат (DCPD), октакальцій фосфат ОСР [8,9].

У випадку електрофоретичної технології (ЕФТ), заряджені колоїдні частинки розчину під дією електричного поля мігрують і осаджуються на субстраті протилежного заряду. У ЕФТ використовуються пересичені або метастабільні водні електроліти, що містять як кальцій, так i 
ортофосфатні іони. Процес грунтується на електрохімічних реакціях в електролітах, внаслідок яких $\mathrm{pH}$ розчину зростає навколо катода. Це призводить до перетворення кислотних ортофосфатних іонів $\mathrm{HPO}_{4}{ }^{2-} \mathrm{i}_{2} \mathrm{PO}_{4}{ }^{-}$ на $\mathrm{PO}_{4}{ }^{3-}$ за одночасного утворення мало розчинної $\mathrm{CaP}$ фази.

При золь-гелевому осадженні передбачається перехід від рідкої «золь» до твердої «гель» фази. Золь-гель технологія створення матеріалів, в тому числі наноматеріалів, включає отримання золю 3 подальшим переведенням його в гель, тобто в колоїдну систему, що складається 3 рідкого дисперсійного середовища, укладеного в просторову сітку, утворену об'єднаними частинками дисперсної фази. На першій стадії процесу реакції гідролізу і поліконденсації призводять до утворення колоїдного розчину золю частинок гідроксидів, розмір яких не перевищує кілька десятків нм. Збільшення об'ємної концентрації дисперсної фази або інша зміна зовнішніх умов ( $\mathrm{pH}$, заміна розчинника, температура) призводять до інтенсивних контактів між частинками i утворення монолітного гелю. Для даного методу існує характерна особливість. Так, при змішуванні двох речовин-прекурсорів осадження не відбувається і розчин залишається гомогенним. Осадження і утворення гелю(осаду) починається тоді, коли під дією якогось фактору що найменше один із реагентів починає змінювати свій хімічний склад. Наявність в реакційному середовищі поверхні субстрату призводить, в першу чергу, до взаємодії твердих частинок, які утворюються, 3 поверхнею субстрату i до їх осадження на цій поверхні. У випадку осадження кальцій фосфатів, гідратовані іони $\mathrm{Ca}^{2+}$ i $\mathrm{PO}_{4}{ }^{3-}$, утворені у водних розчинах відповідних сполук-прекурсорів, осаджуються на субстрати за низьких $\left(100-120^{\circ} \mathrm{C}\right)$ температур реакції та лужних значень $\mathrm{pH}$. Після висушування, залежно від застосованої температури, тверді осади можуть залишатися як однофазними (HA, DCPD), так і утворювати дві або декілька фаз, наприклад, $\mathrm{HA}+\beta$ трикальцій фосфат (ТКФ) при прожарюванні осаду при $900-1100^{\circ} \mathrm{C}[10]$.

Біоміметичне осадження - це метод, за допомогою якого біологічно активні кістковоапатитні відкладення утворюються на субстратах, занурених у різні імітаційні розчини, такі як розчин солі Хенка (HBSS), фосфатний буферний розчин (PBS) або розчин, який імітує фізіологічну рідину (SBF, simulated body fluid). Історично це було в 1990 році, коли $\mathrm{CaP}$ вперше був біологічно осаджений на субстрат [11]. Цей метод передбачає неоднорідне зародження та зростання кристалів заміщеної іонами металів CDHA фази на поверхні імплантатів у фізіологічних умовах (температура субстрату $25-37^{\circ} \mathrm{C}, \mathrm{pH}$ розчину в межах 6-8) протягом декількох днів або навіть тижнів. Утворення покриттів методом занурення $\epsilon$ простою та популярною технікою осадження для різних субстратів. Метод включає кількох послідовних кроків, а саме: і)субстрат занурюється в суспензію покривного матеріалу (у нашому разі СаР) за постійної швидкості; ii) мокрий осад самоосаджується на субстраті під час його виймання 3 розчину, при цьому швидкість виймання визначає товщину (чим швидше - тим тонше); iii) певна частина розчину самовільно зливається 3 поверхні. При висушуванні одночасно 3 випаровуванням розчинника ущільнюється покриття.

Гідротермічне осадження - це простий i один із найбільш економічно ефективних методів, який досить схожий на вищезгадане біоміметичне осадження та волого-хімічне осадження, але гідротермічне оброблення проводиться за підвищених температур $\left(>80^{\circ} \mathrm{C}\right)$ протягом відносно тривалого періоду часу $(>1,5$ год). Після висушування утворювані $\mathrm{CaP}$ покриття є здебільшого кристалічними.

\section{Технологія TSD}

Як зазначалося раніше, TSD грунтується на температурній залежності розчинності осаджуваного матеріалу (наразі $\mathrm{CaP}$ ). Підігрівання металевого титанового субстрату в умовах насиченого водного розчину відповідних сполук кальцію та фосфору забезпечує утворення твердих осадів на субстратах. Запропоновано різні методи нагріву. Можуть бути електропровідні субстрати, такі як металеві фольги або дроти, які нагріваються електричним струмом, пропущеним через них. Безконтактні методи, такі як індукційний нагрів, можуть бути використані для нагрівання матеріалів складної форми, в тому числі непровідних. У таких випадках техніка називається осадженням 3 індукційним нагрівом. Більш детально роботи останнього напрямку представлені в [1]. 


\section{Теоретичні основи TSD}

Всі методики синтезу СaР з водних розчинів прекурсорів визначаються двома стадіями: а) гідроліз та б) осадження. Використання методу термічного осадження для отримання покриттів кальцій фосфатного біоматеріалу засновано на різній розчинності $\mathrm{CaP}$ в залежності від температури розчину. Мірою розчинності певної сполуки являється константа розчинності - Ке. Співвідношення між К температурою розчину $\mathrm{T}\left({ }^{\circ} \mathrm{K}\right)$ виражається формулою [12]

$$
\begin{gathered}
\log \mathrm{K}_{\mathrm{p}}=-8219.41 / \mathrm{T}-1.6657-0.098215 \mathrm{~T} \text { (1) } \\
\text { Із співвідношення витікає, що }
\end{gathered}
$$
максимальна величина К р відповідає $16^{\circ} \mathrm{C}$; тобто зі зростанням температури розчину вище цієї точки, розчинність НА починає зменшуватись. Така ж сама тенденція характерна і для інших ортофосфатів кальцію: DCPD $\left(\mathrm{CaHPO}_{4} * 2 \mathrm{H}_{2} \mathrm{O}-\right.$ мінерал брюшит), DCPA $\left(\mathrm{CaHPO}_{4}-\right.$ мінерал монетит), $\beta$-ТСР [12]. При $25^{\circ} \mathrm{C}, K_{\mathrm{p}}$ згідно (1) дорівнює $3.04 * 10^{-59}\left(\mathrm{~mol} 1^{-1}\right)^{9}$, що добре відповідає експериментальним даним: $2.91 * 10^{-58}$ $\left(\mathrm{mol} \mathrm{l} \mathrm{l}^{-1}\right)^{9}$ [10]. Таким чином, при нагріванні

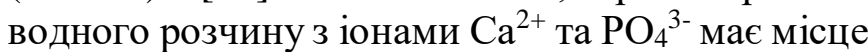
осадження ортофосфатів кальцію, зокрема, НА. Іонний продукт $\left(K_{\text {iп }}\right)$ - добуток концентрацій іонів даного електроліту, який для НА представлений наступним чином:

$$
\mathrm{K}_{\text {iा }}=\left[\mathrm{Ca}^{2+}\right]^{5}\left[\mathrm{PO}_{4}{ }^{3-}\right]^{3}\left[\mathrm{OH}^{-}\right](2)
$$

$[\mathrm{X}]$ - молярна концентрація $\left(\mathrm{mol} \mathrm{l}^{-1}\right)$ іонів $\mathrm{X}$

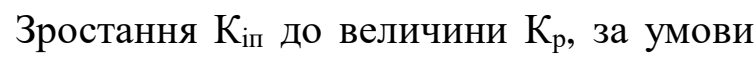
значення $\mathrm{pH}>6,0$ ініціює початок осадження СаР. Експериментально доведено, що для осадження порошкового НА найбільш сприятливим значенням $\mathrm{pH}$ розчину $є$ значення 10 і вище, в той час, як осадження НА на титановий субстрат відбувається при рН 6,3-6,5.

Особливості експериментальних пристроїв TSD

Технологія TSD базується на проходженні змінного струму через металеву пластину, занурену у водний розчин, з метою іiі нагрівання. В даному випадку має місце Джоулеве (резистивне) нагрівання пластини $(\approx$ $\left.100^{\circ} \mathrm{C}\right)$ при атмосферному тиску, потужність якого (P) $є$ пропорційною опору субстрату $(\mathrm{R})$ та квадрату сили струму, який проходить через субстрат $\left(\mathrm{P}=\mathrm{I}^{2} \mathrm{R}\right)$. Ця технологія забезпечує створення реакційних умов для осадження при атмосферному тиску. Зменшення розчинності НА у водному розчині прекурсорів 3 ростом температури та $\mathrm{pH}$ за технології TSD, означає факт осадження реакційних іонів 3 подальшим утворенням НА саме на поверхні розігрітої пластини. При цьому важливо контролювати концентрацію іонів, температуру пластини і $\mathrm{pH}$ розчину, оскільки ці параметри впливають на ступінь перенасичення НА (рівняння (1), (2) [3]. На Рис.1 представлені схеми експериментальних пристроїв для отримання $\mathrm{CaP}$ покриттів з використанням TSD $[3,7]$.


Рис. 1. Схеми апаратурних пристроїв для отримання СаР покриттів: А) [3], Б) [7]. 
Вперше конструкція експериментального пристрою була запропонована групою K.Kuroda [2] 3 кафедри матеріалознавства та техніки Вищої інженерної школи Нагойського університету, Японія (Department of Materials Science and Engineering, Graduate School of Engineering, Nagoya University, Nagoya 464-8603, Japan).

Зусиллями нашої групи при участі вчених 3 Мюнстерського університету (Drs. B. SulkioCleff, C. Moseke), технологія TSD набула подальшого розвитку. Зокрема, була застосована система охолодження для створення градієнту температур між субстратом (Рис.1Б) і материнським розчином, використаний референтний стакан з термопарою для контролю температури розчину в ході експерименту. Крім цього, перемішування здійснювали в контрольному та експериментальному стаканах, що забезпечує однакові умови експерименту.

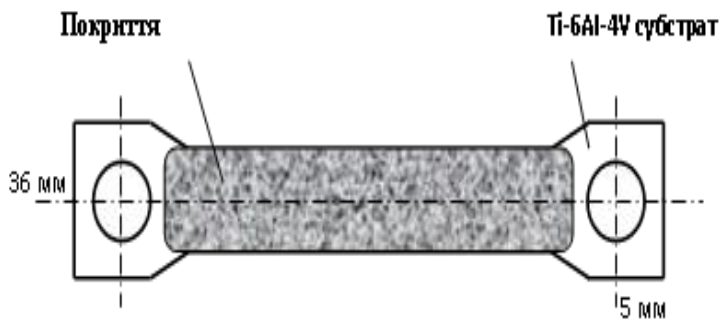

Рис. 2. Загальний вигляд Ti-6Al-4V-субстрату 3 геометричними розмірами $\left(\mathrm{S}_{\text {субстр }}=96 \mathrm{mM}^{2}\right)$ 3 $\mathrm{CaP}$ покриттям отриманим методом TSD [7].

В роботі [13] автори запропонували іншу методику отримання НА покриттів на субстратах, виготовлених 3 матеріалів різного походження, а саме металічних, 3 вмістом кремнію, пластикових (metal Ti, Si wafer, YSZ) (Рис.3).



Рис. 3. Схематичне зображення отримання НА покриттів на субстратах з різних за природою матеріалів [13].

Субстрат розміщували на поверхні водного розчину відповідних сполук кальцію та фосфору. Температура субстрату зростала в результаті індукційного нагріву, при цьому розчинність утворюваних в розчині НА частинок зменшувалась локально навкруги субстрату. Такі умови сприяли осадженню частинок НА на поверхні субстрату. Надмірний нагрів всього об'єму розчину попереджували системою охолодження. Апаратурні схеми TSD 3 індукційним нагрівом можна знайти в [1].

\section{III. ЕКСПЕРИМЕНТАЛЬНА ЧАСТИНА Вплив температури на параметри покриттів}

Структура $\mathrm{CaP}$ покриттів залежить від різних факторів, зокрема таких, як температура синтезу та тривалість процесу. 3 метою вибору оптимального режиму для отримання подібних покриттів, в наших дослідженнях температура субстрату змінювалась в інтервалі 310-393 К 3 кроком 5-10 градусів. Було знайдено, що температура суттєво впливає на такі параметри покриттів як фазовий склад, співвідношення $\mathrm{Ca} / \mathrm{P}$, масу покриття наступним чином: з ростом температури субстрату від $319{ }^{\circ} \mathrm{K}$ до $393{ }^{\circ} \mathrm{K}$ спостерігалось зростання маси покриття (М) від 0.005 г до 0.0340 г, а співвідношення $\mathrm{Ca} / \mathrm{P}($ ат \%) від 1.08 до 1.8, відповідно. (Рис. 4) [14].

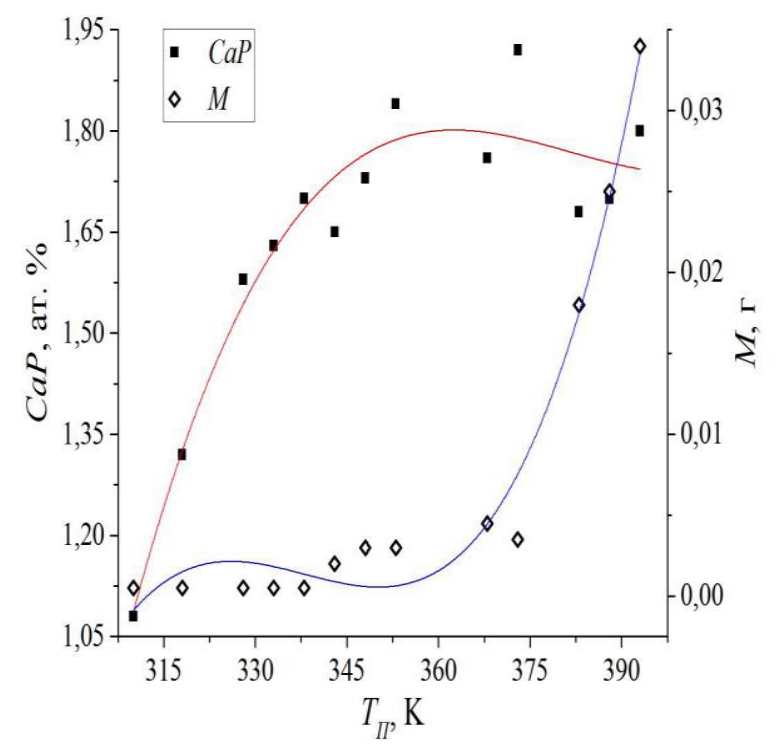

Рис. 4. Залежність співвідношення Са/Р (ат.\%) та маси покриттів (г), отриманих на титанових субстратах методом TSD, від температури субстрату $\left(\mathrm{T}_{\Pi},{ }^{\circ} \mathrm{K}\right)$ [14].

Покриття 3 фазою НА відповідають температурному інтервалу їх осадження 373-383 ${ }^{\circ} \mathrm{K}$ та значенню $\mathrm{pH} \leq 6,5$. Для покриттів, отриманих за температур $348,353^{\circ} \mathrm{K} \mathrm{i} \mathrm{pH} \approx 6,68$, в області основних піків апатиту $\left(2 \theta \sim 31-33^{\circ}\right)$ присутне гало, що вказує на наявність нанокристалічного апатиту. У покриттях, 
отриманих за температур від 358 до $393 \mathrm{~K} \mathrm{i} \mathrm{pH} \mathrm{=}$ 6,5-6,6, основною фазою $є$ HA (JCPDS 9-432). Інші фази відсутні. В той же час, при температурах $388-393{ }^{\circ} \mathrm{K}$ покриття має пористу (діаметр пор d 100-150 мкм) дрібнокристалічну структуру, що $є$ результатом кипіння рідини у приповерхневому шарі покриття. Результати вивчення мікроструктури та елементного складу покриттів показали, що оптимальним часом для отримання покриттів HA методом TSD є 60 хв за температури від 373 К. Зниження температури субстрату призводить до відповідного збільшення часу осадження для досягнення однакової товщини покриття.

Однофазні СаР покриття: НА та DCPD (мінерал брюшит), нанесені на поверхню Ti6Al4V субстратів, оксидовану плазмаелектролітичним методом (PEO, plasma electrolytic oxidizing).

Пролонговано-захисна дія СаР покриттів залежить від їх біосумісності та здатності протидіяти агресивному біологічному середовищу, в якому знаходиться імплантат. Підвищення механічних властивостей покриттів на основі СаР можливе шляхом їх осадження на спеціально оброблену поверхню титанового субстрату, що забезпечить покриттю високий ступінь його адгезії. Одним 3 видів такої попередньої поверхневої обробки субстрату може бути утворення пористого оксидного шару плазмо електролітичним методом окислення 3 наступним попереднім збагаченням його іонами кальцію та фосфору. PEO - це поєднання високовольтного розряду 3 електрохімічним (мікродуговим) окисленням. РЕО шари характеризуються високими механічними властивостями, корозійною стійкістю, міцним зв'язком 3 поверхнею та біоактивністю [15]. В недавній роботі [16] були вперше отримані однофазні HA та DCPD покриття на PEO оброблених Ti6A14V субстратах 3 використанням TSD технології та досліджені їх структурно-морфологічні особливості. Отримання покриттів стало можливим завдяки використанню фундаментальної властивості $\mathrm{CaP}$ сполук, а саме залежності їх розчинності (Кр) від температури водного розчину (розділ 2.1.1). Серед різних ортофосфатів кальцію, DCPD і HA мають особливий науковий інтерес через близькість їх хімічної структури та поведінки in vivo до структури неорганічної частини нативної кістки. Як показано в [16],
DCPD фаза була утворена на PEO обробленому субстраті при його нагріванні до $85^{\circ} \mathrm{C}$, а НА фаза - при $140^{\circ} \mathrm{C}$. К Кі для DCPD (по аналогії 3 рівнянням (2) для НА) є наступним:

$$
\begin{aligned}
& \mathrm{K}_{\mathrm{in}}(\mathrm{DCPD})=\left[\mathrm{Ca}^{2+}\right] \cdot\left[\mathrm{HPO}_{4}^{2-}\right](3) \\
& \text { За умови } \mathrm{K}_{\text {iп }}=\mathrm{K}_{\mathrm{p}} \text { (максимальна }
\end{aligned}
$$
розчинність) при відповідних температурах розчину має місце осадження HA або DCPD, для яких $\lg \mathrm{K}_{\mathrm{p}}^{\mathrm{DCPD}} 85=-59.8 \mathrm{i} \lg \mathrm{K}_{\mathrm{p}}^{\mathrm{HA}} 140=-62.1$. Таким чином, при використанні TSD варіювання температурою субстрату дозволяє отримати задане монофазне HA або DCPD покриття. Оскільки $\mathrm{K}_{\mathrm{p}}{ }^{\mathrm{DCPD}} 85>\mathrm{K}_{\mathrm{p}}{ }^{\text {ГА }} 140$, при більш низькій температурі відбувається утворення DCPD, а при більш високій - НА. Цікаво, що отримані покриття мають різну швидкість осадження, що впливає на їх товщину, отриману за 30 хвилин, а саме: DCPD - 50 мкм, HA - 300 мкм. Покриття мають також різну форму кристалітів: для НА характерна як голчаста, так i пластинчаста форма, тоді як для DCPD - переважно голчаста форма (Рис.5). Морфологія отриманих покриттів визначається як температурою їх осадження, так і структурою молекул речовини, яка утворює покриття. Молекула НА (молекулярна маса (MM) 1004) має гексагональну решітку, тоді як DCPD (MM 172) має моноклинну решітку. Значна різниця між ММ цих молекул обумовлює переважне зростання кристалів DCPD порівняно до НА кристалів. Відповідно до гістограм розподілу за розмірами (Рис. $5, \mathrm{C}, \mathrm{F}$ ), середні розміри кристалітів фракцій HA та DCPD складають 4,4 і 7 мкм, відповідно. Пористість утворених покриттів контролюється в основному вищезазначеним температурним фактором. За даними скануючої електронної мікроскопії (SEM) середній розмір пор становить 5 і 8 мкм для покриттів HA і DCPD, відповідно. Обидва покриття $є$ достатньо однорідними по розподілу на поверхні субстрату. 

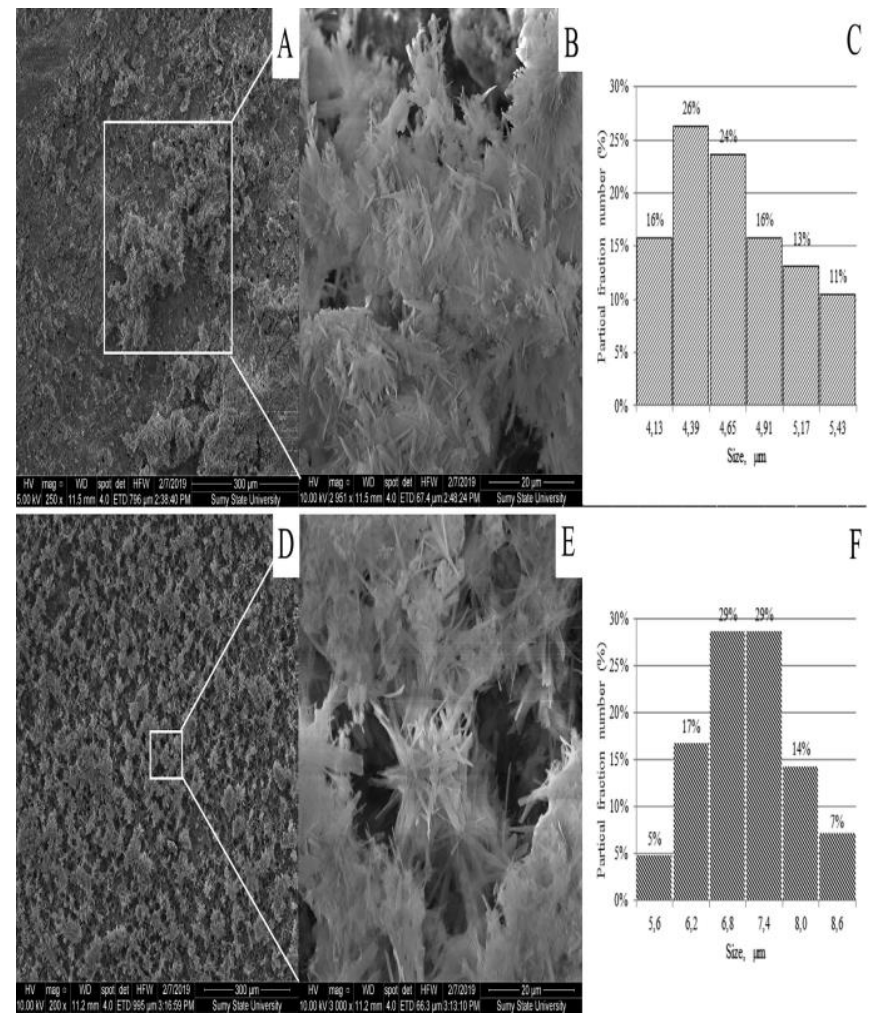

Рис.5. SEM зображення (при різному збільшенні) морфології покриттів НА (A, B) i DCPD (D, E), осаджених на PEO оброблені Ti6Al4V субстрати. Гістограми розподілу за розмірами HA (C) та DCPD (F) кристалітів [16]

\section{Гібридні НА-біополімерні покриття}

Взаємодія імплантату з організмом людини в першу чергу відбувається через його поверхню. Тому поверхневі модифікації імплантату мають важливе значення для посилення його біосумісних, остеокондуктивних та остеоіндуктивних властивостей. Добре відомо, що СаР покриття, завдяки біосумісності 3 клітинами кальціфікованих тканин (остеобласти, остеокласти, фібробласти), мають великий потенціал застосування в кістковій хірургії та тканинній інженерії. Зокрема, подібні покриття можна модифікувати з метою отримання певних кристалографічних фаз заданого хімічного складу, кристалічності і ступеню резорбції [17]. До складу таких покриттів, за умови використання «м яких» біоміметичних методів осадження, можна вносити певні біополімери, біоактивні молекули, лікарські засоби з метою надання покриттям додаткових функцій i властивостей, зокрема, антибактеріальних та протизапальних.

\section{CS - CaP покриття}

Хітозан-полісахарид природного походження, який характеризується присутністю гідроксильних та аміно груп, які визначають його розчинність та біоактивність [18] (Рис. 6). Доведено, що CS відноситься до біодеградуючих, біосумісних, нетоксичних, неалергенних, біоадгезійних біополімерів [19]. Біоматеріали з вмістом CS сприяють адсорбції, диференціації та проліферації стовбурових клітини, остеобластів, остеоцитів [19]. Наприклад, CS-HA гідрогелі демонструють хорошу спорідненість до остеобластів, підтримку життєздатності та проліферації цих клітин, а також сприяють біомінералізації, остеогенній диференціації ранній стадії [20].

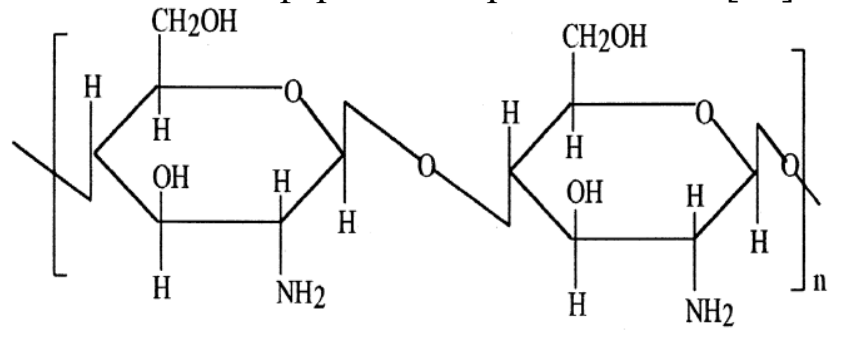

Рис. 6. Хімічна структура хітозану

CS та його похідні, наприклад, четвертинний амонійний $\mathrm{CS}$, підвищують антибактеріальну дію, біологічну резорбцію та остеогенну активність гібридного цементу на основі сполук кальцію та кремнію (Ca-Si) [21]. Присутність в хімічному ланцюзі хітозану протонованих в кислотному середовищі аміно груп $\left(\mathrm{NH}_{3}{ }^{+}\right) \mathrm{n}$ надає його макромолекулам унікальних полікатіонних властивостей, які забезпечують взаємодію 3 негативно зарядженими іонами та біомолекулами, зокрема, протеїнами та пептидами. Нашою групою був проведений цикл досліджень, присвячений отриманню CS-HA покриттів методом TSD та їх дослідженню різними інструментальними методами [6,22,23]. Було розроблено три способи внесення макромолекул CS в HA покриття з застосуванням TSD методу (Рис. 7): a) попереднє нанесення CS на субстрат методом окунання 3 подальшим TSD осадженням шару CaP на утворену CS плівку; б) TSD осадження $\mathrm{CaP}$ з подальшою обробкою осаду розчином CS; в) одночасне TSD осадження $\mathrm{CaP}$ та CS на субстрат маточного розчину, який містить одночасно як CS, так і прекурсори для утворення $\mathrm{CaP}$ [14]. Найбільш привабливим способом 
внесення CS до складу покриттів є способи а) i B) [24].

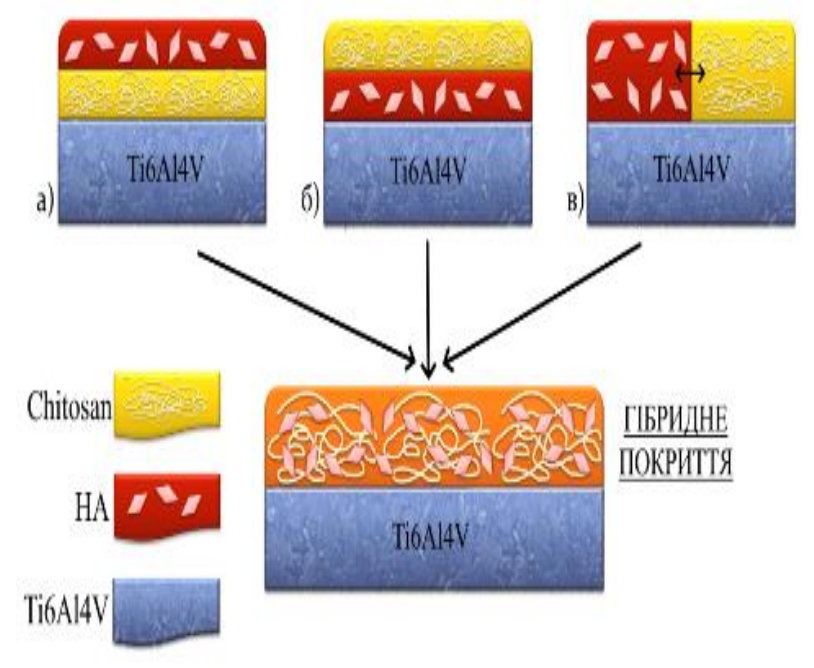

Рис. 7. Схема отримання CS-HА покриттів на модельному титановому імплантаті методом TSD

Структурні та субструктурні особливості отриманих покриттів були досліджені методом рентгенівської дифракціїі (XRD) на приладі DRON-3 (LTD “Burevestnik”, www.bourevestnik.ru). Рентгенівські дифрактограми отриманих композитних покриттів свідчать про присутність нанокристалічного НА, кристалічність якого зменшувалась зі збільшенням частки CS. Знайдено, що при співвідношенні CS:HA=50:50 розміри кристалітів в композиті відповідають розміру кристалітів біоапатиту кісткової тканини ( 20 нм). Щільна поверхня отриманих CS-HA покриттів, за даними PEM, є гладкою, без розшарування на мінеральну та органічну складові. Результати кількісної оцінки атомарного співвідношення $\mathrm{Ca} / \mathrm{P}$ демонструють підвищений вміст атомів Са у порівнянні зі стехіометричним $\mathrm{HA} \quad(\mathrm{Ca} / \mathrm{P}=1.67)$ I збільшенням співвідношення CS:HA у покриттях зростає і атомарне співвідношення $\mathrm{Ca} / \mathrm{P}$, яке для $\mathrm{CS}: \mathrm{HA}=15: 85$ становить 1.78 , для $\mathrm{CS}: \mathrm{HA}=50: 50-1.93$, для CS:HA=80:20 - 2,15. Отримані покриття мали також задовільні механічні характеристики: твердість за Віккерсом для зразків CS:HA $=15: 85,30: 70$, 50:50, 80:20 дорівнює 0.22, 0.15, 0.12, і 0.14 ГПа, відповідно. Ці значення $є$ співставними 3 величиною 0,396 ГПа для кортікальної кістки [25]. Пористість отриманих композитних покриттів визначалась умовами ліофілізації (температура, тривалість, початкова вологість) і вихідним

співвідношенням

CS:HA.

Макромолекули CS мають здатність утворювати хелатні комплекси 3 іонами металів, зокрема, іонами срібла $\left(\mathrm{Ag}^{+}\right)$. Для отримання допованих $\mathrm{Ag}^{+}$покриттів логічно внести спочатку $\mathrm{Ag}^{+} \mathrm{y}$ материнський розчин для TSD, який містить як CS, так і розчини сполук кальцію та фосфору (спосіб с). Дослідження показали, що при додаванні CS до материнського TSD розчину спостерігається підвищення концентрації срібла в покриттях від $4.75 \mathrm{мг/Г} \mathrm{(для} \mathrm{розчину,} \mathrm{що}$ містить 25\% Ag, 75\% НА) до $6.4 \mathrm{мг/ \Gamma} \mathrm{(для}$ розчину з $25 \% \mathrm{CS}, 25 \% \mathrm{Ag}, 50 \% \mathrm{HA}$ ), незважаючи на однакову кількість доданого розчину срібла. Це обумовлено саме зазначеною властивістю молекул CS зв'язуватись 3 іонами $\mathrm{Ag}^{+}$, переходячи в нерозчинний стан в умовах TSD експерименту (pH 6,72) [24]. Дослідження покриттів на основі НА з додаванням CS та $\mathrm{Ag}^{+}$ в якості антимікробних компонентів показали їх протимікробну активність щодо мікроорганізмів E.coli ATCC 25922. При цьому антибактеріальна активність була пролонгованою, і після 48 годин протимікробна дія покриттів $\mathrm{CS} / \mathrm{HA}+\mathrm{Ag}^{+}$була найвищою у порівнянні 3 контрольним НА покриттям. Отримані результати можна пояснити синергічною дією хітозану та іонів срібла, як протимікробних компонентів.

\section{HA-ZnO/Alg покриття}

Вищевикладена TSD технологія, як показують літературні джерела, успішно використовується для отримання СаР покриттів на Ті субстратах декількома науковими групами $[2,3,4,6,7,13]$. В той же час, нещодавно ця технологія була вперше використана для нанесення поверхневого відносно тонкого $\mathrm{ZnO}$ шару на попередньо отримане НА-покриття на Ti субстраті (двошарове покриття) [26,27]. Коротко, суть технології полягає в наступному.

Приготування поверхні Ti субстрату. Поверхню субстрату перед осадженням шліфували папером $\mathrm{SiC}$ і промивали етанолом та деіонізованою водою в ультразвуковому очищувачі з наступним анодуванням протягом 1 години при кімнатній температурі в електроліті $\left(\mathrm{H}_{2} \mathrm{SO}_{4}-20 \% \quad \mathrm{w} / \mathrm{w} ; \mathrm{NaF}-0,5 \% \quad \mathrm{w} / \mathrm{w}\right)$ для утворення шару $\mathrm{TiO}_{2}$ на поверхні. Свинцева пластина використовувалась як катод, а титановий субстрат в якості аноду. Після анодної оксидації титановий субстрат відпалювали при температурі $500^{\circ} \mathrm{C}$ протягом 1 години в муфельній печі з подальшою обробкою 
етанолом та промиванням деіонізованою водою (Рис. 7). На підготований за такою методикою субстрат наносили методом TSD двошарове (3 НА та $\mathrm{ZnO}$ ) покриття.

Отримання НА покриття (перший шар). Осадження НА проводили на титановому субстраті з розчину об'ємом 200 мл, що містить $0,01 \mathrm{M} \mathrm{CaCl} 2$ та $0,006 \mathrm{M} \mathrm{H}_{3} \mathrm{PO}_{4}(\mathrm{pH} 6,52)$. Через анодований титановий субстрат, занурений в підготовлений розчин, протягом 60 хвилин пропускали змінний електричний струм (2A), в результаті чого субстрат нагрівався до $95^{\circ} \mathrm{C}$. Зміна температури субстрату була каталізатором осадження НА покриття згідно хімічної реакції

$5 \mathrm{CaCl}_{2}+3 \mathrm{H}_{3} \mathrm{PO}_{4}+10 \mathrm{NaOH} \rightarrow \mathrm{Ca} 5\left(\mathrm{PO}_{4}\right)_{3} \mathrm{OH}+10 \mathrm{NaCl}+9 \mathrm{H}_{2} \mathrm{O}$

Отримання HA-ZnO/Alg покриття.

Отримане вище НА покриття використовували як нижній шар у двошаровому $\mathrm{HA}-\mathrm{ZnO} / \mathrm{Alg}$ покритті. Субстрат, покритий шаром НА, ретельно промивали деіонізованою водою 3 наступним зануренням у розчин для осадження $\mathrm{ZnO} / \mathrm{Alg}$ плівки. Присутність макромолекул $\mathrm{Alg}$ (Рис. 8) у робочому розчині впливає на кристалізацію і розміри кристалітів $\mathrm{ZnO}$, а також у комплексі 3 наночастинками $\mathrm{ZnO}$ надає покриттю додаткових антибактеріальних властивостей. Для порівняння, нанесення $\mathrm{ZnO}$ покриття безпосередньо на титанові субстрати проводилося також методом TSD. Середовище для покриття готували наступним чином: до 200 мл $0,2 \mathrm{M}$ водного розчину $\mathrm{Zn}\left(\mathrm{NO}_{3}\right)_{2} \times 6 \mathrm{H}_{2} \mathrm{O}$ додавали по краплях при інтенсивному перемішуванні 30 мл 25\% аміаку для отримання прозорого лужного розчину, що містить $\mathrm{ZnO}$ наночастинки, які утворювались згідно наступної хімічної реакції [28]: $\mathrm{Zn}^{2+}+4 \mathrm{OH}^{-} \rightarrow \mathrm{Zn}(\mathrm{OH})_{4^{2-}} \mathrm{i} \mathrm{Zn}(\mathrm{OH})_{4}{ }^{2-} \rightarrow \mathrm{ZnO}+2 \mathrm{H}_{2} \mathrm{O}+2 \mathrm{OH}^{-}$

Анодований Ti6Al4V субстрат був занурений у підготовлений розчин і протягом 20 хвилин через субстрат пропускався змінний електричний струм силою $2 \mathrm{~A}$, в результаті чого субстрат нагрівався до $80^{\circ} \mathrm{C}$. Це створило сприятливі умови реакції для осадження наночастинок $\mathrm{ZnO}$ на поверхні субстрату. Для утворення $\mathrm{ZnO} / \mathrm{Alg}$ покриття, 3 г альгінату натрію розчиняли в 100 мл $0,01 \mathrm{M} \mathrm{NaOH}$ і 4 мл цього лужного розчину по краплях додавали до вище описаного материнського розчину при інтенсивному перемішуванні. Отриманий колоїдний розчин гомогенізували в шейкері (200 об/хв) протягом 1 години при кімнатній температурі (Рис. 7). Таким чином, два види $\mathrm{ZnO}$ покриттів було отримано та досліджено: $\mathrm{ZnO} / \mathrm{Alg}$ - покриття, нанесене 3 розчину 3 вмістом полімеру $\mathrm{Alg}$ та $\mathrm{ZnO}$ покриття з розчину без вмісту біополімеру. Очевидно, що присутність у маточному розчині $\mathrm{Alg}$ істотно впливає на утворення покриттів, тому вони відрізняються за морфологією. У присутності альгінату утворюються кристали у формі тетраедрів, тоді як 3 розчину, що не містить полімеру, утворюються кулеподібні та у формі квітки кристали (Рис. 8). Товщина покриття $\mathrm{ZnO}$, нанесеного протягом 20 хв на титановий субстрат, становить 180 мкм, тоді як товщина покриття $\mathrm{ZnO} / \mathrm{Alg}$, нанесеного за той же час, становить 600 мкм. Середня швидкість осадження 3 розчину 3 вмістом альгінату становить $30 \mathrm{м \kappa м/хв,} \mathrm{в} \mathrm{той} \mathrm{час,} \mathrm{як} \mathrm{з} \mathrm{розчину} \mathrm{без}$ вмісту альгінату - 9 мкм/хв. Кристалічність фази $\mathrm{ZnO}$ в отриманому без додавання полімеру покритті $є$ вищою, ніж у $\mathrm{ZnO} / \mathrm{Alg}$, в той же час інтенсивність більшості піків для зразка $\mathrm{ZnO} / \mathrm{Alg}$ є вищою, що обумовлено більшою товщиною покриття в цьому випадку.

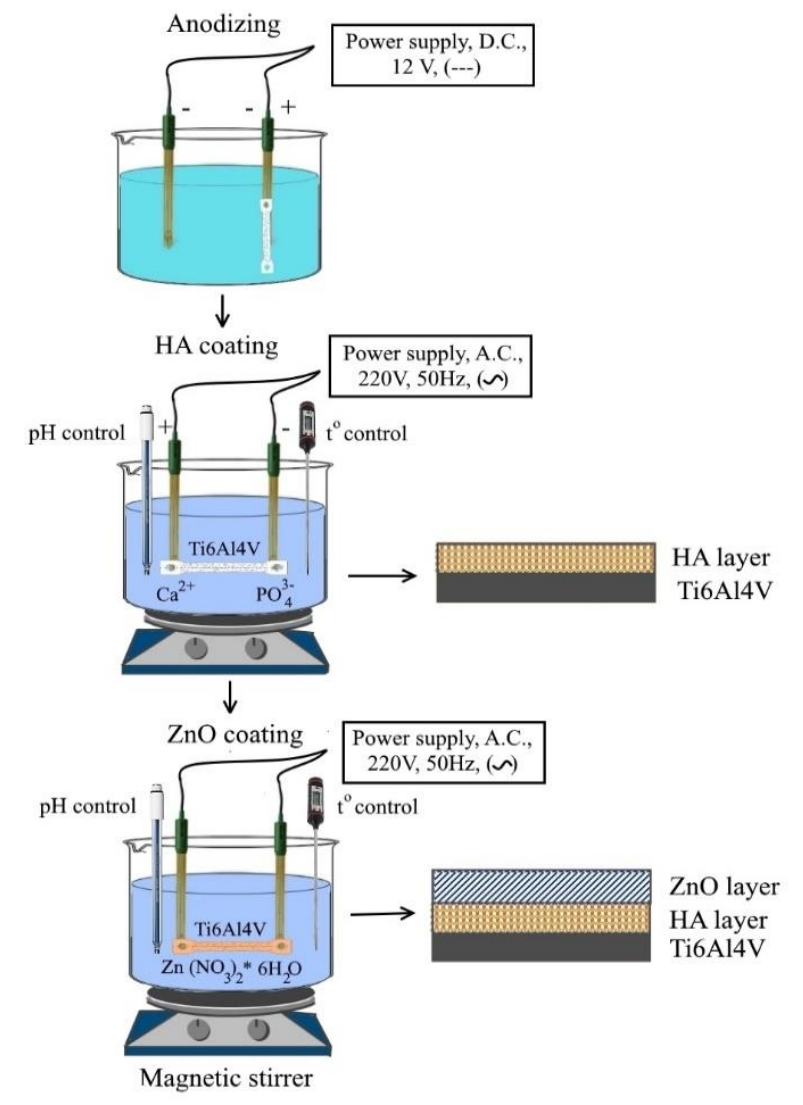

Рис. 8. Схема нанесення двошарового покриття НA-ZnO / Alg на анодовану підкладку Ti6Al4V методом TSD [26] 


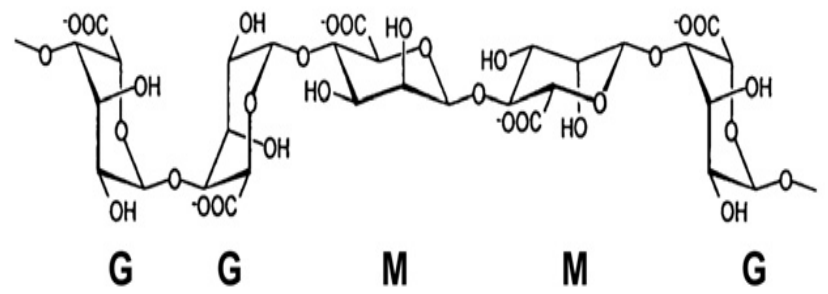

Рис. 9. Структурна характеристика альгінату в ланцюговій конформації бінарного сополімера, який складається 3 $(1 \rightarrow 4)$ пов'язаних залишків $\beta$-D-мануронової кислоти $(\mathbf{M})$ та $\alpha$-L-гулуронової кислоти (G) [29]
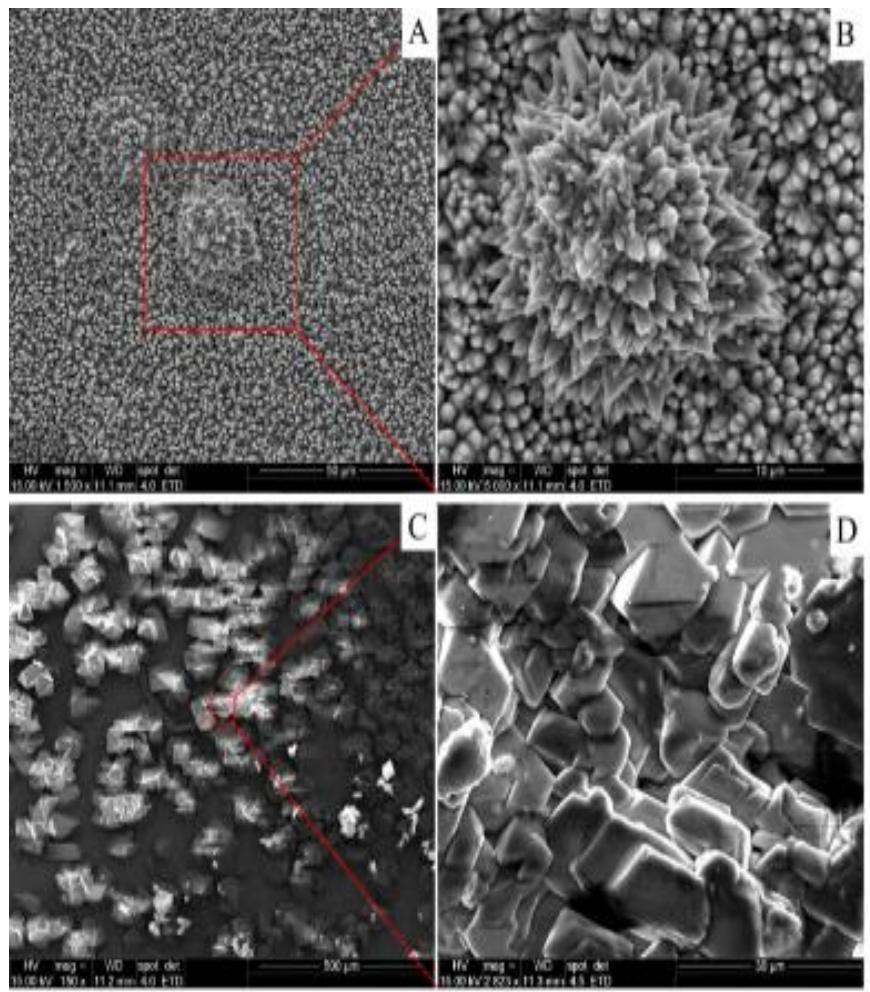

Рис. 10. Морфологія поверхні покриттів, отриманих TSD методом на титановому субстраті: (A), (B) - ZnO при різних збільшеннях; (C), (D) - $\mathrm{ZnO} / \mathrm{Alg}$ при різних збільшеннях [27]

Зміни в структурній організації покриттів зумовлені впливом альгінату. Макромолекули $\mathrm{Alg}$ в присутності $\mathrm{Zn}^{2+}$, як правило, приймають впорядковане положення шляхом димеризації [30], тому вони створюють контрольовані умови для росту наночастинок $\mathrm{ZnO}$. Антибактеріальну активність покриття $\mathrm{ZnO} / \mathrm{Alg}$ досліджували щодо грам-негативних (E.coli АТCC 25922) та грам-позитивних (S. Aureus АТCC 25923) бактерій методом дифузії в агар та визначали зону пригнічення росту мікробних клітин. Ріст бактерій візуалізували після інкубації субстратів протягом ночі при $37^{\circ} \mathrm{C}$ на твердому поживному середовищі. Зона інгібування (3I) росту (мм) навколо покритих субстратів відображає антимікробний вплив покриття (Рис. 11).

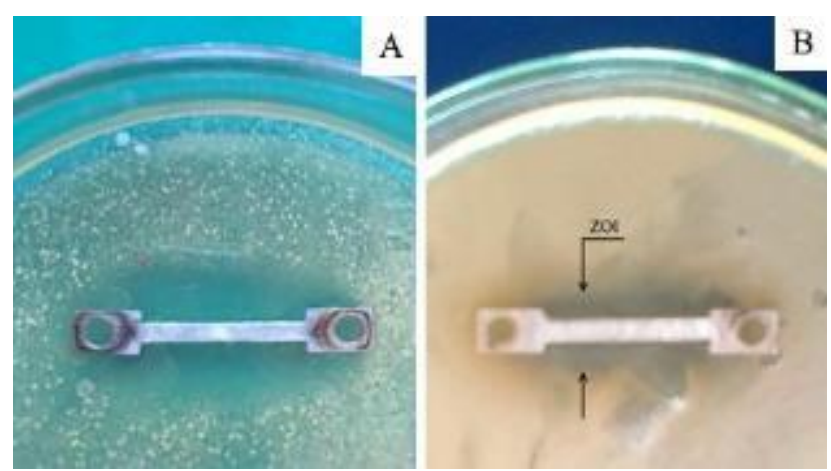

Рис. 11. Антимікробна активність покриття $\mathrm{ZnO} / \mathrm{Alg}$ щодо (А) E. coli ATCC 25922 - 3I = 20.0 \pm 0.66 ; (B) $S$. aureus ATCC $25923-3 \mathrm{I}=16.0 \pm 1.33(\mathrm{p} \leq 0.05)$ [27].

Таким чином, наночастинки $\mathrm{ZnO}$, осаджені в присутності макромолекул Alg на титановий субстрат методом TSD, демонструють виражену інгібуючу активність як у відношенні бактерій S.aureus ATCC 25923, так і E.coli ATCC 25922. Наразі запропоновані механізми протимікробної дії включають як утворення реактивних видів кисню (ROS) на поверхні наночастинок оксиду металу, так i вивільнення іонів металів $\mathrm{Zn}^{2+}$ та їх вторгнення у клітинну стінку бактерій, що провокує пряме механічне руйнування мембрани та спричиняє загибель бактеріальної клітини $[31,32]$. Сучасні досягнення в сфері металевих імплантатів пов'язані 3 підвищенням їх біосумісності, антибактеріальної активності, відсутності токсичності, швидкої остеоінтеграції, що повністю відповідає сучасним клінічним вимогам. Результати викладених досліджень є ще одним кроком в цьому напрямку, а саме в створенні багатофункціональних біоактивних поверхонь титанових імплантатів.

\section{Колаген (Cg)/НА покриття}

В роботі [3] для отримання $\mathrm{Cg} / \mathrm{HA}$ покриттів методом TSD використовували водний розчин ( $\mathrm{pH} 8$ ), який складався з $0.3 \mathrm{MM} \mathrm{Ca}\left(\mathrm{H}_{2} \mathrm{PO}_{4}\right)_{2}, 0.7$ $\mathrm{MM} \mathrm{CaCl}_{2}$ та 432 мг/дм ${ }^{3}$ кислоторозчинного $\mathrm{Cg}$ (тип I). Покриття осаджували на титанові стрижні (діаметром 2 мм, довжиною 5 мм) або пластини (товщиною $0.3 \mathrm{mм}$ ), які занурювали в 0.2 дм $^{3}$ водного розчину і під час нагрівання (шляхом пропускання електричного струму) опромінювали ультразвуком (100 кГц) для прискорення кристалізації НА. Вміст Сg в покриттях розраховували, виходячи 3 кількості вуглецю, який вимірювали у вигляді виділеного $\mathrm{CO}_{2}$ при прожарюванні покриттів при $600^{\circ} \mathrm{C}$ в 
атмосфері $\mathrm{O}_{2}$ [3]. In vivo дослідження на щурах показали, що додавання $\mathrm{Cg}$ сприяло збільшенню остеопровідності покриття. При цьому максимальне значення контакту кісткового імплантату (остеопровідний індекс = довжина сформованої кістки на поверхні імплантату/загальна довжина імплантату х 100 $\%$ було отримано в тому разі, коли відносний вміст колагену відповідав його вмісту природній кістці. Перевищення цієї кількості колагену гальмувало поліпшення остеопровідності [3]. Слід зазначити, що подібні $\mathrm{Cg} / \mathrm{HA}$ покриття на Ti субстратах отримували із використанням іншого методу хімічної модифікації поверхні, а саме, електрохімічного осадження [33]. Автори стверджують, що включення до складу покриття біоактивних макромолекул, в тому числі специфічних сигнальних молекул для селективного зв'язування 3 остеобластами i ростовими факторами (РФ) (ВМР-2, фібробластові РФ, тощо), сприяе кістковій інтеграції, яка, в свою чергу, залежить від адгезії, проліферації і диференціації кістковоутворюючих клітин - остеобластів. Одним із перспективних підходів в отриманні $\mathrm{Cg} / \mathrm{HA}$ покриттів являється комбінація електрофоретичного осадження молекул колагену i електролітичного осадження НА. Більш детально процес отримання покриття 3 мінералізованих колагенових фібрил представлений в [33]. Процес включає декілька стадій (Рис. 11):

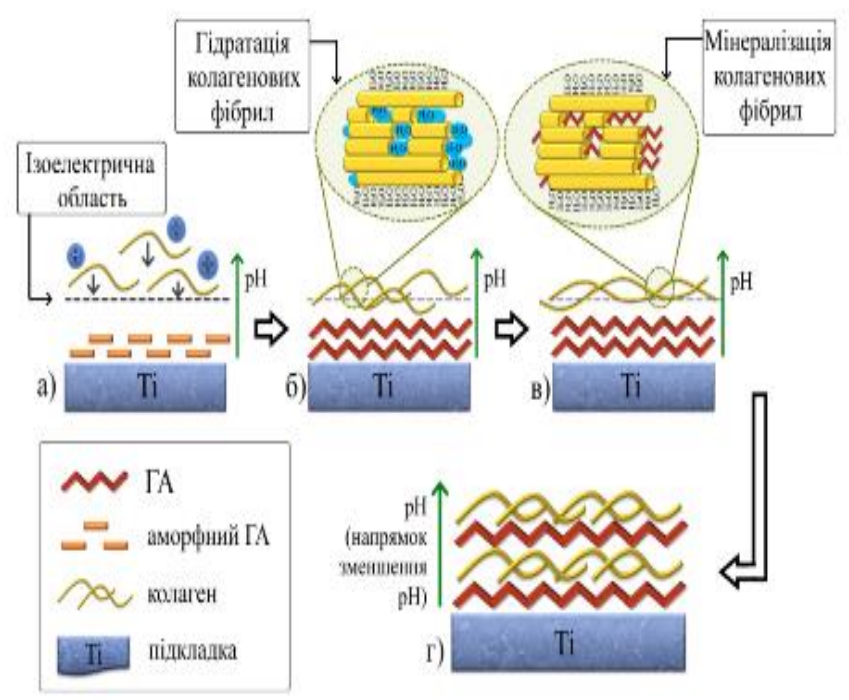

Рис. 11. Схема формування мінералізованого колагенового покриття з використанням електрохімічного осадження [33, 34].
Автори вважають [33], що при включенні електричного поля, $\mathrm{pH}$ розчину біля катоду зростає завдяки генерації $\mathrm{OH}^{-}$іонів $\left(2 \mathrm{H}_{2} \mathrm{O}+2 \mathrm{e}\right.$ $\left.\rightarrow \mathrm{H}_{2} \uparrow+2 \mathrm{OH}^{-}\right)$. Це призводить до нуклеації $\mathrm{i}$ утворення аморфного НА. Макромолекули Сg позитивно зарядженими в електроліті ( $\mathrm{pH} \sim 4.5)$ і тому рухаються до катоду (Рис. 11a). Поблизу катода в умовах, які відповідають ізоелектричній точці колагену, має місце самоорганізація нейтральних макромолекул у фібрили (Рис. 11б). Кальцій-фосфатна мінералізація колагенових фібрил відбувається через негативно заряджені карбоксильні групи колагену, які $\epsilon$ ключовими сайтами нуклеації $\mathrm{CaP}$ (Рис. 11в). В той же час, завдяки високому значенню рН біля катоду, має місце осадження HA iз розчину 3 одночасним осадженням мінералізованих колагенових фібрил під дією електричного поля (Рис. 11г). Процес росту СаР кристалів в мінералізованому колагені після осадження продовжується завдяки присутності іонів $\mathrm{Ca}^{2+}, \mathrm{PO}_{4}{ }^{3-}$. Одночасно відбувається з`єднання осадженого колагену 3 HA, утворюючи розвинуту структуру гібридного покриття [33,34].

\section{Фулерен С6-НA-CS покриття}

В цьому розділі коротко представлені результати нещодавніх досліджень щодо отримання фулеренС60-вмісних (F) покриттів на основі HA та CS 3 додатковими протимікробними властивостями. Фулерен С60, як одна 3 кількох алотропних модифікацій вуглецю, має унікальну структуру, що включає $\mathrm{sp}^{2}$ зв'язки вуглецю, які утворюють високо симетричну решітку. Молекула С60 $\epsilon$ акцептором електронів, а значить $\epsilon$ окислювачем і може утворювати реактивні види кисню (ROS), зокрема, в разі опромінення ультрафіолетом $[35,36]$. Його дисперсія може викликати антиоксидантні властивості в організмі, головним чином шляхом нейтралізації та/або приєднання АТР (аденозинтрифосфат) вільних радикалів. При виконанні експериментів були використані наступні реактиви: безводний кальцій хлорид $\mathrm{CaCl}_{2}$, ортофосфорна кислота $\mathrm{H}_{3} \mathrm{PO}_{4}$, натрію гідроксид $\mathrm{NaOH}$ (виробництво “Merk"), хітозан (M.M.100-300 кДа, ACROS ORGANIC, USA), фулерен C60 - водний колоїдний розчин із середнім розміром частинок 50 нм, комерційно доступний фармацевтичний диклофенак натрію, 25 мг/мл. Всі реагенти були аналітичного класу 
чистоти. Експериментально було визначено, що структура HA-CS та HA-CS-F покриттів, утворених з розчинів прекурсорів методом TSD, змінюється залежно від $\mathrm{pH}$ розчину, температури та концентрації утворюючих іонів в маточному розчині. Визначено, що при $\mathrm{pH}>6$ переважаючим компонентом отриманих на титанових субстратах покриттів $€$ кальцій дефіцитний гідроксиапатит (кдНА). Додавання фулерену нівелює роль $\mathrm{pH}$ та сприяє більш ефективному осадженню HA-CS-F покриттів (Рис. 13). Знайдено, що температура субстрату $100 \pm 3{ }^{\circ} \mathrm{C}$ оптимальною для отримання покриттів HA-CS-F методом TSD.

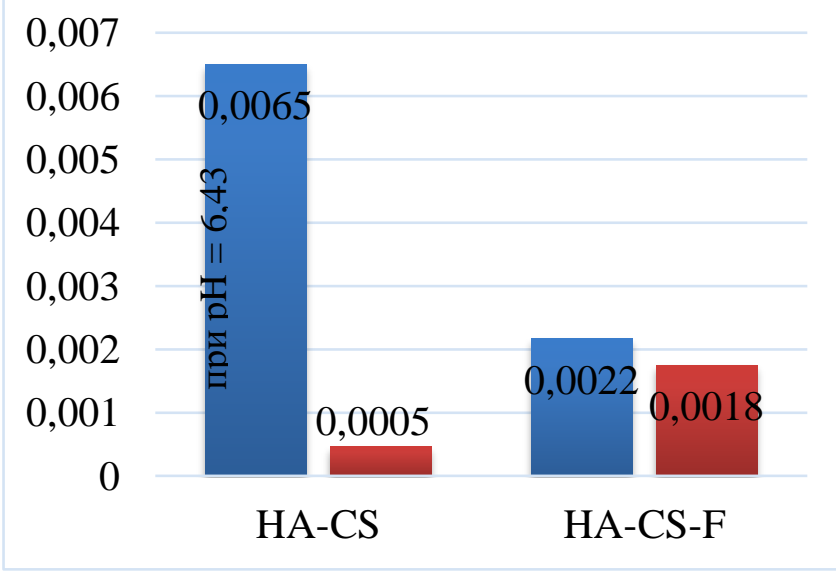

Рис. 13. Вплив значення $\mathrm{pH}$ на процес осадження зразків 3 вмістом фулерену HA-CS-F та без фулерену HA-CS при $\mathrm{pH}=6,43$ (синім кольором) та при $\mathrm{pH}=6,73$ (червоним кольором).

\section{Протимікробна активність ряду покриттів на основі НА.}

Зважаючи на підвищену резистентність мікроорганізмів до широкого ряду антибіотиків в останнє десятиліття, вчені намагаються знайти альтернативні речовини в якості протимікробних засобів $[37,38]$. Саме тому до складу покриттів було внесено частинки неорганічного походження, а саме фулерен С60, наночастинки срібла $\mathrm{Ag}_{\mathrm{nano}} \mathrm{ZnO}$ та іони срібла $\mathrm{Ag}^{+}$в якості протимікробних агентів. На Рис.14 приведено зображення протимікробної активності щодо мікроорганізму $S$. Aureus ATCC 25923 ряду покриттів на основі НА, а саме: на основі НА та CS ( в якості контрольного для порівняння); НА-CS з вмістом фулерену різної концентрації (300 мкл/мл та 600 мкл/мл); HA-CS 3 вмістом іонів $\mathrm{Ag}^{+}$та наночастинок Agnano; HA-CS з вмістом протимікробного лікарського засобу - хлоргексидину. Результати свідчать, що найменшу протимікробну активність проявляє зразок HA-CS, який не містить додаткових протимікробних

домішок.

Незначна протимікробна активність цього зразку відбувається завдяки присутності CS та пояснюється тим, що при приєднанні позитивно зарядженої протонованої $\mathrm{NH}^{3+}$ групи $\mathrm{CS}$ до поверхні мікробної клітини порушується іiі метаболізм, що призводить до загибелі клітини. Молекули CS, леговані іонами металів, в тому числі $\mathrm{Ag}^{+}$, мають вищий протимікробний ефект [39]. Даний факт підтверджується дослідженням зразків з вмістом іонів та наночастинок срібла. Так, зразки HA-CS-Ag ${ }^{+}$та HA-CS-Agnano (Рис. 14) демонстують зони інгібування росту мікроорганізмів 6,4 мм та 8,2 мм, відповідно. Зразки з вмістом фулерену в кількості 300 та 600 мкл/мл також проявляють протимікробну активність, забезпечуючи зони затримки росту мікроорганізмів (33Р) в розмірі 6 та 5 мм, відповідно. Дослідження свідчать, що майже однакові 33Р демонструють зразки, вміст фулерену в яких відрізняється вдвічі. Це може бути пов'язано $з$ тим, що великі концентрації можуть бути токсичні, у той час як малі проявляють антимікробну дію. На даний момент, ведеться багато досліджень 3 визначення оптимальних концентрацій фуллерену для максимального антимікробного ефекту. 33Р зразка 3 вмістом лікарського препарату хлоргекседину складає 15,4 мм. Хлоргексидин добре розчинним протимікробним засобом, його дифузія до мембрани мікробної клітини є більш інтенсивною в порівнянні 3 нерозчинними наночастинками фулерену, оксиду цинку та срібла.
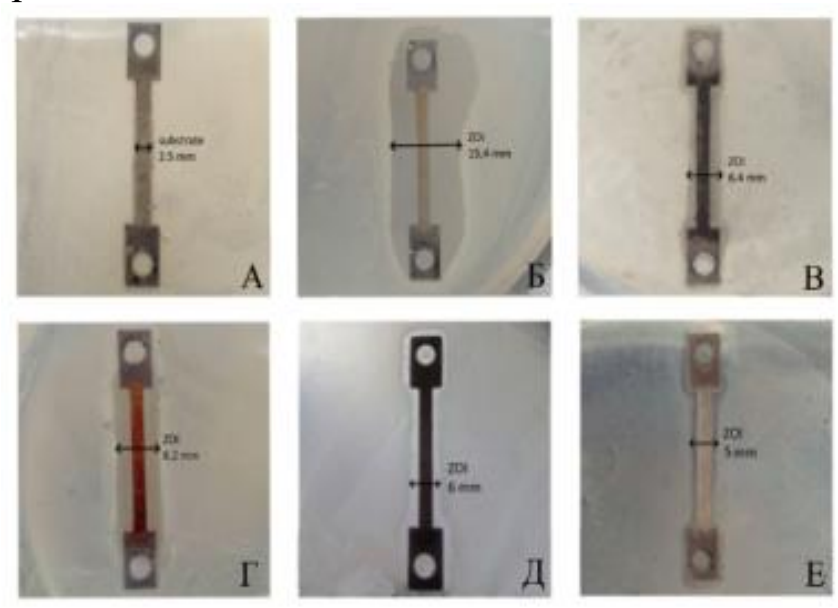

Рис.14. Протимікробна активність зразків: А) HA-CS; Б)НА-CS-хлоргексидин; В) HA-CS-Ag $;$; ) HA-CS-Agnano; Д) HA-CS-F (300 мкл/мл); Е) НА-CS-F (600 мкл/мл). 


\section{IV. ВИСНОВКИ TА ПЕРСПЕКТИВИ}

3 наведеного огляду витікає, що ефективність функціонування медичних імплантатів може бути підвищена завдяки формуванню на їх поверхні біоактивних покриттів мікрометричної товщини. Серед багатьох технологій осадження, розроблених протягом останніх двох десятиліть, низькотемпературна технологія термодепозиції, яка базується на явищі залежності розчинності фосфатів кальцію від температури, $є$ найперспективнішою для отримання гібридних багатофункціональних апатит-біополімерних покриттів різної морфології та фазового складу. В огляді наданий аналіз отриманих результатів щодо синтезу та структурно-фазових досліджень апатит-біополімерних покриттів, отриманих методом TSD в лабораторії «Біонанокомпозит» Сумського державного університету протягом останніх 5 років. На початку відмічені особливості інших популярних технологій (плазмове розпилення, осадження парів - PVD, CVD, вологі методи електрофоретичне та електрохімічне осадження, золь-гель, біоміметичне осадження) та структурно-морфологічні особливості отриманих покриттів. Далі розглянути теоретичні основи TSD 3 акцентом на аналіз температурної залежності розчинності найголовніших компонентів покриттів - НА та DCPD, та особливості експериментальних пристроїв TSD. Знайдено, що температура субстрату впливає на такі параметри як фазовий склад, $\mathrm{Ca} / \mathrm{P}$, масу (М) покриття. Так, за температур осадження $319{ }^{\circ} \mathrm{K}$ та $393{ }^{\circ} \mathrm{K}, \mathrm{M}$ зростає від 0.005 г до 0.0340 г, співвідношення $\mathrm{Ca} / \mathrm{P}$ (ат\%) від 1.08 до 1.8 , відповідно. Оптимальними умовами для отримання покриття з фазою НА є час 60 хв за температури від $373{ }^{\circ}$ К. Плазмо-електролітичний метод окислення (PEO) був використаний для попередньої обробки Ti6Al4V субстратів 3 подальшим отриманням однофазних (НА та DCPD) покриттів при температурах субстрату $140^{\circ} \mathrm{C}$ та $85^{\circ} \mathrm{C}$, відповідно. При цьому середні розміри частинок-агломератів HA та DCPD складають відповідно 4,4 і 7 мкм. Оскільки TSD відноситься до «м яких» методів осадження, це дозволяє створити умови для отримання більш ефективних покриттів завдяки можливості введення до їх складу біополімерів та лікарських засобів. Такі домішки надають покриттям додаткових

функцій,

зокрема,

антибактеріальних, протизапальних. У випадку CS-HA покриттів було знайдено, що одночасне осадження неорганічного НА та органічного полімеру CS є найбільш привабливим 3 точки зору нанокристалічності і розміру кристалітів HA: при CS:HA = 50:50 - розміри кристалітів НА в композиті відповідають розміру кристалітів біоапатиту кісткової тканини ( 20 нм), а твердість за Віккерсом узгоджується 3 твердістю для кортикальної кістки: 0.22 ГПа проти 0.396 ГПа, відповідно. У випадку НА$\mathrm{ZnO} / \mathrm{Alg}$ покриттів, присутність макромолекул впливає на морфологію отриманих структур: Alg сприяє утворенню кристалів у формі тетраедрів. Макромолекули Alg в присутності $\mathrm{Zn}^{2+}$, приймають упорядкований вид шляхом димерилізації, створюючи умови для контрольованого росту наночастинок $\mathrm{ZnO}$. Останні демонструють виражену інгібуючи активність щодо бактерій S.aureus та E.coli. Додавання колагену в покриття за літературними даними сприяє покращенню остеопровідності, причому максимальне значення контакту кісткового імплантату було отримано за умови, коли відносний вміст колагену був наближеним до вмісту у природній кістці. Одним із перспективних підходів в отриманні $\mathrm{Cg} / \mathrm{HA}$ покриттів являється комбінація електрофоретичного осадження молекул колагену і електролітичного осадження НА. Зважаючи на підвищену резистентність мікроорганізмів до широкого ряду антибіотиків в останні десятиліття, вчені намагаються знайти альтернативні речовини в якості протимікробних засобів. Саме тому до складу покриттів було внесено частинки неорганічного походження, а саме фулерен С60, наночастинки срібла $\mathrm{Ag}_{\text {nano, }} \mathrm{ZnO}$ та іони срібла $\mathrm{Ag}^{+}$в якості протимікробних агентів. Виходячи 3 наведеного аналізу можливостей TSD в отриманні гібридних гідроксиапатит-біополімерних покриттів на Тi субстратах, можна зробити висновок щодо перспективності подальшого розвитку цього напрямку досліджень 3 метою отримання багатофункиіональних біопокриттів, які відповідають сучасним клінічним вимогам хірургічної імплантології.

Подяка. Автор висловлює щиру вдячність за співпрацю, а саме - прочитання огляду, суттєвого доповнення та технічну допомогу в 
його оформленні к.х.н. Суходуб Л.Б. та аспірантці Кумуді М.О.

\section{V. ПЕРЕЛІК ПОСИЛАНЬ}

1. Dorozhkin, S. V. Calcium orthophosphate deposits: Preparation, properties and biomedical applications. Materials Science and Engineering: C. 2015. Vol. 55.

2. Kuroda, K., Miyashita, Y., Ichino, R., та ін. Preparation of Calcium Phosphate Coatings on Titanium Using the Thermal Substrate Method and Their \&lt;I\&gt;in vitro\&lt;/I\&gt; Evaluation. MATERIALS TRANSACTIONS. 2002. Vol. 43, No. 12.

3. Kuroda, K., Okido, M. Hydroxyapatite Coating of Titanium Implants Using Hydroprocessing and Evaluation of Their Osteoconductivity. Bioinorganic Chemistry and Applications. 2012. Vol. 2012.

4. Sukhodub, L. B., Moseke, C., Sukhodub, L. F., та ін. Improved thermal substrate method with cooling system for hydroxyapatite coatings on titanium substrates: Annual Report, Münster, Institut für Kernphysik Westfalishe Wilhelmsuniversität, 03. C. 86-88.

5. Yanovska, A. A., Kuznetsov, V. N., Danilchenko, S. N., та ін. Obtaining of uniform hydroxyapatite-based coatings by thermal substrate method. . Biophysical Bulletin. 2010. Vol. 25, No. 2. C. 131-144.

6. Yanovska, A., Danilchenko, S., Sukhodub, L. Fabrication Of Nanocomposite Calcium-Phosphate Coatings By Thermal Substrate Method: Comprehensive Guide For Nanocoatings Technology: / за ред. М. Aliofkhazraei. Nova Science Publishers, 2015.

7. Sukhodub, L. F., Yanovska, G. O., Sukhodub, L. В., та ін. Nanocomposite Apatite-Biopolymer Materials And Coatings For Biomedical Applications. Journal Of Nano- And Electronic Physics . 2014. Vol. 6, No. 1.

8. Kim, H.-M., Himeno, T., Kokubo, Т., та ін. Process and kinetics of bonelike apatite formation on sintered hydroxyapatite in a simulated body fluid. Biomaterials. 2005. Vol. 26, No. 21.

9. Wang, L., Nancollas, G. H. Calcium Orthophosphates: Crystallization and Dissolution. Chemical Reviews. 2008. Vol. 108, No. 11.

10. Cheng, K., Zhang, S., Weng, W., та iн. The adhesion strength and residual stress of colloidal-sol gel derived $\beta$-TricalciumPhosphate/Fluoridated-Hydroxyapatite biphasic coatings. Thin Solid Films. 2008. Vol. 516, No. 10.

11. Kokubo, T., Ito, S., Huang, Z. T., та ін. Ca, P-rich layer formed on high-strength bioactive glass-ceramic A-W. Journal of Biomedical Materials Research. 1990. Vol. 24, No. 3.

12. Elliott, J. Structure and Chemistry of the Apatites and Other Calcium Orthophosphates: Amsterdam-London-NewYork-Tokyo: Elsevier Science, 1994. undefined-404c.

13. MIYAZAKI, H., MAEDA, H., YOSHIDA, S., та ін. Deposition of hydroxyapatite thin films from saturated calcium phosphate solution by controlling the substrate temperature. Journal of the Ceramic Society of Japan. 2014. Vol. 122, No. 1429.

14. Кузнецов, В. М. КРИСТАЛІЧНА СТРУКТУРА ТА МОРФОЛОГІЯ ПОКРИТТІВ I МАТЕРІАЛІВ НА ОСНОВІ НАНОРОЗМІРНИХ АПАТИТУ ТА БРУШИТУ ПІД ВПЛИВОМ ФІЗИКО-ХІМІЧНИХ ФАКТОРІВ / Суми: 2017.

15. Durdu, S., Deniz, Ö. F., Kutbay, I., та ін. Characterization and formation of hydroxyapatite on Ti6Al4V coated by plasma electrolytic oxidation. Journal of Alloys and Compounds. 2013. Vol. 551.

16. Sukhodub, L. F., Sukhodub, L. B., Simka, W., та ін. Hydroxyapatite and brushite coatings on plasma electrolytic oxidized Ti6Al4V alloys obtained by the thermal substrate deposition method. Materials Letters. 2019. Vol. 250.

17. Sukhodub, L., Panda, A., Suchodub, L., та ін. HYDROXYAPATITE AND ZINC OXIDE BASED TWO-LAYER COATING, DEPOSITED ON TI6AL4V SUBSTRATE. MM Science Journal. 2019. Vol. 2019, No. 05.
18. Conrado Aparicio, Maria Pau Ginebra. Biomineralization and Biomaterials, Fundamentals and Applications: 2016.

19. Qin, Y., Li, P. Antimicrobial Chitosan Conjugates: Current Synthetic Strategies and Potential Applications. International Journal of Molecular Sciences. 2020. Vol. 21, No. 2.

20. Tao, F., Ma, S., Tao, H., та ін. Chitosan-based drug delivery systems: From synthesis strategy to osteomyelitis treatment - A review. Carbohydrate Polymers. 2021. Vol. 251.

21. Demirtaş, T. T., Irmak, G., Gümüşderelioğlu, M. A bioprintable form of chitosan hydrogel for bone tissue engineering. Biofabrication. 2017. Vol. 9, No. 3 .

22. Lin, M.-C., Chen, C.-C., Wu, I.-T., та ін. Enhanced antibacterial activity of calcium silicate-based hybrid cements for bone repair. Materials Science and Engineering: C. 2020. Vol. 110.

23. Yanovska, G. O. ., Kuznetsov, V. M. ., Stanislavov, O. S. ., та ін. Hydroxyapatite coatings formation on modified $\mathrm{Ti}-6 \mathrm{Al}-4 \mathrm{~V}$ substrates. . Chemistry, Physics and Technology of Surface. 2013. Vol. 4, No. 3. C. 340-346.

24. Yanovska, G. O. ., Kuznetsov, V. M. ., Stanislavov, O. S. ., та ін. Coatings based on hydroxyapatite, chitosan and silver for biomedical application. Chemistry, Physics and Technology of Surface. 2012. Vol. 3, No. 3. C. 37-43.

25. Яновська, Г. О. ФІЗИКО-ХІМІЧНІ ОСОБЛИВОСТІ ФОРМУВАННЯ КАЛЬЦЙ-ФОСФАТНИХ ПОКРИТТІВ НА ТИТАНОВИХ ТА МАГНІЕВИХ МОДЕЛЬНИХ ІМПЛАНТАТАХ / Суми: 2014.

26. Pramanik, S., Agarwal, A. K., Rai, K. N. Development of High Strength Hydroxyapatite for Hard Tissue Replacement . Trends Biomater. Artif. Organs. 2005. Vol. 19, No. 1. C. 45- undefined.

27. Sukhodub, L., Sukhodub, L., Kumeda, M., та ін. ZnO Coatings on Ti6Al4V Substrate: Structural and Antibacterial Properties in Literature Review and Research. Management Systems in Production Engineering. 2020. Vol. 28, No. 4.

28. Zhang, Y., Mu, J. Controllable synthesis of flower- and rod-like $\mathrm{ZnO}$ nanostructures by simply tuning the ratio of sodium hydroxide to zinc acetate. Nanotechnology. 2007. Vol. 18, No. 7.

29. Draget, K. I., Taylor, C. Chemical, physical and biological properties of alginates and their biomedical implications. Food Hydrocolloids. 2011. Vol. 25, No. 2.

30. Brayner, R., Vaulay, M.-J., Fiévet, F., та ін. Alginate-Mediated Growth of $\mathrm{Co}, \mathrm{Ni}$, and CoNi Nanoparticles: Influence of the Biopolymer Structure. Chemistry of Materials. 2007. Vol. 19, No. 5. 31. Sirelkhatim, A., Mahmud, S., Seeni, A., та ін. Review on Zinc Oxide Nanoparticles: Antibacterial Activity and Toxicity Mechanism. Nano-Micro Letters. 2015. Vol. 7, No. 3.

32. Sharma, N., Jandaik, S., Kumar, S., та ін. Synthesis, characterisation and antimicrobial activity of manganese- and irondoped zinc oxide nanoparticles. Journal of Experimental Nanoscience. 2016. Vol. 11, No. 1.

33. Developments and Applications of Calcium Phosphate Bone Cement : / за ред. Changsheng Liu, Hongyan He. Singapore Pte Ltd: 2018.

34. Sukhodub, L. ., Moseke, C., Sukhodub, L. ., та ін. Collagenhydroxyapatite-water interactions investigated by XRD, piezogravimetry, infrared and Raman spectroscopy. Journal of Molecular Structure. 2004. Vol. 704, No. 1-3.

35. Grebinyk, A., Grebinyk, S., Prylutska, S., та ін. C60 fullerene accumulation in human leukemic cells and perspectives of LEDmediated photodynamic therapy. Free Radical Biology and Medicine. 2018. Vol. 124.

36. Ritter, U., Prylutskyy, Y. I., Evstigneev, M. Р., та ін. Structural Features of Highly Stable Reproducible C 60 Fullerene Aqueous Colloid Solution Probed by Various Techniques. Fullerenes, Nanotubes and Carbon Nanostructures. 2015. Vol. 23, No. 6.

37. Geng, Z., Wang, R., Zhuo, X., та ін. Incorporation of silver and strontium in hydroxyapatite coating on titanium surface for enhanced antibacterial and biological properties. Materials Science and Engineering: C. 2017. Vol. 71. 
38. Vranceanu, D. M., Parau, A. C., Cotrut, C. M., та ін. In vitro evaluation of $\mathrm{Ag}$ doped hydroxyapatite coatings in acellular media. Ceramics International. 2019. Vol. 45, No. 8.

39. Sukhodub, L. Antimicrobial activity of $\mathrm{Ag}+, \mathrm{Cu} 2+, \mathrm{Zn} 2+, \mathrm{Mg} 2+$ ions doped chitosan nanoparticles. Annals of Mechnikov Institute. 2015. Vol. 1. C. 39-43.

\section{REFERENCES}

[1] S. V. Dorozhkin, "Calcium orthophosphate deposits: Preparation, properties and biomedical applications," Mater. Sci. Eng. C, vol. 55, Oct. 2015, doi: 10.1016/j.msec.2015.05.033.

[2] K. Kuroda, Y. Miyashita, R. Ichino, M. Okido, and O. Takai, "Preparation of Calcium Phosphate Coatings on Titanium Using the Thermal Substrate Method and Their \&lt;I\&gt;in vitro\&lt;/I\&gt; Evaluation," Mater. Trans., vol. 43, no. 12, 2002, doi: 10.2320/matertrans.43.3015.

[3] K. Kuroda and M. Okido, "Hydroxyapatite Coating of Titanium Implants Using Hydroprocessing and Evaluation of Their Osteoconductivity," Bioinorg. Chem. Appl., vol. 2012, 2012, doi: 10.1155/2012/730693.

[4] L. B. Sukhodub, C. Moseke, L. F. Sukhodub, and et al., "Improved thermal substrate method with cooling system for hydroxyapatite coatings on titanium substrates," in Annual Report, 2003, pp. 86-88.

[5] A. A. Yanovska, V. N. Kuznetsov, S. N. Danilchenko, and L. F. Sukhodub, "Obtaining of uniform hydroxyapatite-based coatings by thermal substrate method. ," Biophys. Bull., vol. 25, no. 2, pp. 131-144, 2010.

[6] A. Yanovska, S. Danilchenko, and L. Sukhodub, "Fabrication Of Nanocomposite Calcium-Phosphate Coatings By Thermal Substrate Method," in Comprehensive Guide For Nanocoatings Technology, M. Aliofkhazraei, Ed. Nova Science Publishers, 2015.

[7] L. F. Sukhodub, G. O. Yanovska, L. B. Sukhodub, V. M. Kuznetsov, and O. S. Stanislavov, "Nanocomposite ApatiteBiopolymer Materials And Coatings For Biomedical Applications," J. Nano- Electron. Phys., vol. 6, no. 1, 2014.

[8] H.-M. Kim, T. Himeno, T. Kokubo, and T. Nakamura, "Process and kinetics of bonelike apatite formation on sintered hydroxyapatite in a simulated body fluid," Biomaterials, vol. 26, no. 21, Jul. 2005, doi: 10.1016/j.biomaterials.2004.11.022.

[9] L. Wang and G. H. Nancollas, "Calcium Orthophosphates: Crystallization and Dissolution," Chem. Rev., vol. 108, no. 11, Nov. 2008, doi: $10.1021 / \mathrm{cr} 0782574$.

[10] K. Cheng, S. Zhang, W. Weng, K. A. Khor, S. Miao, and Y. Wang, "The adhesion strength and residual stress of colloidal-sol gel derived $\beta$-Tricalcium-Phosphate/Fluoridated-Hydroxyapatite biphasic coatings," Thin Solid Films, vol. 516, no. 10, Mar. 2008, doi: 10.1016/j.tsf.2007.11.115.

[11] T. Kokubo et al., "Ca, P-rich layer formed on high-strength bioactive glass-ceramic A-W," J. Biomed. Mater. Res., vol. 24, no. 3, Mar. 1990, doi: 10.1002/jbm.820240306.

[12] J. Elliott, Structure and Chemistry of the Apatites and Other Calcium Orthophosphates, 1st ed., vol. 18. Amsterdam-LondonNewYork-Tokyo: Elsevier Science, 1994.

[13] H. MIYAZAKI, H. MAEDA, S. YOSHIDA, H. SUZUKI, and T. OTA, "Deposition of hydroxyapatite thin films from saturated calcium phosphate solution by controlling the substrate temperature," J. Ceram. Soc. Japan, vol. 122, no. 1429, 2014, doi: 10.2109/jcersj2.122.835.

[14] В. М. КУзНецов, “КРИСТАЛІЧНА СТРУКТУРА ТА МОРФОЛОГІЯ ПОКРИТТІВ I МАТЕРІАЛІВ НА ОСНОВІ НАНОРОЗМІРНИХ АПАТИТУ ТА БРУШИТУ ПІД ВПЛИВОМ ФІЗИКО-ХІМІЧНИХ ФАКТОРІВ,” СУми, 2017.

[15] S. Durdu, Ö. F. Deniz, I. Kutbay, and M. Usta, "Characterization and formation of hydroxyapatite on Ti6Al4V coated by plasma electrolytic oxidation," J. Alloys Compd., vol. 551, Feb. 2013, doi: 10.1016/j.jallcom.2012.11.024.

[16] L. F. Sukhodub, L. B. Sukhodub, W. Simka, and M. Kumeda, "Hydroxyapatite and brushite coatings on plasma electrolytic oxidized Ti6Al4V alloys obtained by the thermal substrate deposition method," Mater. Lett., vol. 250, Sep. 2019, doi: 10.1016/j.matlet.2019.05.018.

[17] Conrado Aparicio and Maria Pau Ginebra, Biomineralization and Biomaterials, Fundamentals and Applications, Elsevier. 2016.

[18] Y. Qin and P. Li, "Antimicrobial Chitosan Conjugates: Current Synthetic Strategies and Potential Applications," Int. J. Mol. Sci., vol. 21, no. 2, Jan. 2020, doi: 10.3390/ijms21020499.

[19] F. Tao et al., "Chitosan-based drug delivery systems: From synthesis strategy to osteomyelitis treatment - A review," Carbohydr. Polym., vol. 251, Jan. 2021, doi: 10.1016/j.carbpol.2020.117063.

[20] T. T. Demirtaş, G. Irmak, and M. Gümüşderelioğlu, "A bioprintable form of chitosan hydrogel for bone tissue engineering," Biofabrication, vol. 9, no. 3, Jul. 2017, doi: 10.1088/17585090/aa7b1d.

[21] M.-C. Lin, C.-C. Chen, I.-T. Wu, and S.-J. Ding, "Enhanced antibacterial activity of calcium silicate-based hybrid cements for bone repair," Mater. Sci. Eng. C, vol. 110, May 2020, doi: 10.1016/j.msec.2020.110727.

[22] G. O. . Yanovska, V. M. . Kuznetsov, O. S. . Stanislavov, and L. F. Sukhodub, "Hydroxyapatite coatings formation on modified Ti-6Al-4V substrates. ," Chem. Phys. Technol. Surf., vol. 4, no. 3, pp. 340-346, 2013.

[23] G. O. . Yanovska, V. M. . Kuznetsov, O. S. . Stanislavov, and V. Y. Illiashenko, "Coatings based on hydroxyapatite, chitosan and silver for biomedical application.," Chem. Phys. Technol. Surf., vol. 3, no. 3, pp. 37-43, 2012.

[24] Г. О. Яновська, “ ФІЗИКО-ХІМІЧНІ ОСОБЛИВОСТІ ФОРМУВАННЯ КАЛЬЦЙ-ФОСФАТНИХ ПОКРИТТІВ НА ТИТАНОВИХ ТА МАГНІЕВИХ МОДЕЛЬНИХ ІМПЛАНТАТАХ,” Суми, 2014.

[25] S. Pramanik, A. K. Agarwal, and K. N. Rai, "Development of High Strength Hydroxyapatite for Hard Tissue Replacement ," Trends Biomater. Artif. Organs., vol. 19, no. 1, pp. 45-undefined, 2005.

[26] L. Sukhodub, A. Panda, L. Suchodub, M. Kumeda, K. Dyadyura, and I. Pandova, "HYDROXYAPATITE AND ZINC OXIDE BASED TWO-LAYER COATING, DEPOSITED ON TI6AL4V SUBSTRATE," MM Sci. J., vol. 2019, no. 05, Dec. 2019, doi: 10.17973/MMSJ.2019_12_2019030.

[27] L. Sukhodub, L. Sukhodub, M. Kumeda, A. Panda, and P. Baron, "ZnO Coatings on Ti6Al4V Substrate: Structural and Antibacterial Properties in Literature Review and Research," Manag. Syst. Prod. Eng., vol. 28, no. 4, Dec. 2020, doi: 10.2478/mspe-20200045.

[28] Y. Zhang and J. Mu, "Controllable synthesis of flower- and rod-like $\mathrm{ZnO}$ nanostructures by simply tuning the ratio of sodium hydroxide to zinc acetate," Nanotechnology, vol. 18, no. 7, Feb. 2007, doi: 10.1088/0957-4484/18/7/075606.

[29] K. I. Draget and C. Taylor, "Chemical, physical and biological properties of alginates and their biomedical implications," Food Hydrocoll., vol. 25, no. 2, Mar. 2011, doi: 10.1016/j.foodhyd.2009.10.007.

[30] R. Brayner, M.-J. Vaulay, F. Fiévet, and T. Coradin, "Alginate-Mediated Growth of $\mathrm{Co}, \mathrm{Ni}$, and $\mathrm{CoNi}$ Nanoparticles: Influence of the Biopolymer Structure," Chem. Mater., vol. 19, no. 5, Mar. 2007, doi: 10.1021/cm062580q.

[31] A. Sirelkhatim et al., "Review on Zinc Oxide Nanoparticles: Antibacterial Activity and Toxicity Mechanism," Nano-Micro Lett., vol. 7, no. 3, Jul. 2015, doi: 10.1007/s40820-0150040-x.

[32] N. Sharma, S. Jandaik, S. Kumar, M. Chitkara, and I. S. Sandhu, "Synthesis, characterisation and antimicrobial activity of manganese- and iron-doped zinc oxide nanoparticles," J. Exp. Nanosci., vol. 11, no. 1, Jan. 2016, doi: 10.1080/17458080.2015.1025302. 
[33] Changsheng Liu and Hongyan He, Eds., Developments and Applications of Calcium Phosphate Bone Cement, Springer Nature. Singapore Pte Ltd, 2018.

[34] L. . Sukhodub et al., "Collagen-hydroxyapatite-water interactions investigated by XRD, piezogravimetry, infrared and Raman spectroscopy,” J. Mol. Struct., vol. 704, no. 1-3, Oct. 2004, doi: 10.1016/j.molstruc.2003.12.061.

[35] A. Grebinyk et al., "C60 fullerene accumulation in human leukemic cells and perspectives of LED-mediated photodynamic therapy," Free Radic. Biol. Med., vol. 124, Aug. 2018, doi: 10.1016/j.freeradbiomed.2018.06.022.

[36] U. Ritter et al., "Structural Features of Highly Stable Reproducible C 60 Fullerene Aqueous Colloid Solution Probed by
Various Techniques," Fullerenes, Nanotub. Carbon Nanostructures, vol. 23, no. 6, Jun. 2015, doi: 10.1080/1536383X.2013.870900.

[37] Z. Geng et al., "Incorporation of silver and strontium in hydroxyapatite coating on titanium surface for enhanced antibacterial and biological properties," Mater. Sci. Eng. C, vol. 71, Feb. 2017, doi: 10.1016/j.msec.2016.10.079.

[38] D. M. Vranceanu et al., "In vitro evaluation of Ag doped hydroxyapatite coatings in acellular media," Ceram. Int., vol. 45, no. 8, Jun. 2019, doi: 10.1016/j.ceramint.2019.02.191.

[39] L. Sukhodub, "Antimicrobial activity of $\mathrm{Ag}+, \mathrm{Cu} 2+$, $\mathrm{Zn} 2+, \mathrm{Mg} 2+$ ions doped chitosan nanoparticles," Ann. Mechnikov Inst., vol. 1, pp. 39-43, 2015.

\title{
ГИБРИДНЫЕ АПАТИТ- БИОПОЛИМЕРНЫЕ ПОКРЫТИЯ, ПОЛУЧЕННЫЕ МЕТОДОМ ТЕРМИЧЕСКОЙ ДЕПОЗИЦИИ НА МОДЕЛЬНЫХ ИМПЛАНТАТАХ ИЗ ТИТАНА И ЕГО СПЛАВОВ
}

\author{
Суходуб Л.Ф., \\ sukhodub@yahoo.com \\ доктор физ.-мат.наук \\ профессор, член-кореспондент НАН Украины \\ кафедра биофизики, биохимии, \\ фармакологии биомолекулярной инженерии. \\ Сумской государственный университет, \\ медицинский институт, \\ г.Сумы, Украина
}

Peфepam - Проблематика-разработка и производство покрытий для медицинских имплантатов составляют существенный сегмент современного рынка технологий. Учитывая количество больных, которым требуется операция по восстановлению целостности костной ткани, объемы необходимых материалов оцениваются на уровне десятков тонн. Цель исследования - анализ разработок и технологий биомиметического получения многофункциональных биосовместимых наноструктурированных покрытий на основе ортофосфатов кальция (CaP) и природных биополимеров хитозана (CS), альгината (Alg), коллагена (Cg) в виде двухфазных систем металл/покрытие. Методика - использование технологии термической депозиции (TSD-temperature substrate deposition) из водных растворов прекурсоров. Результаты: В данном обзоре просуммированы научные данные о методах получения биоактивных, противомикробных СаР покрытий и исследование их свойств. Отмеченны особенности популярных технологий: плазменное распыление, электрофоретическое и электрохимическое осаждение, золь-гель, биомиметическое осаждение. Учитывая повышенную резистентность микроорганизмов к широкому ряду антибиотиков в последние десятилетия, в качестве противомикробных средств в состав покрытий были внесены альтернативные частицы неорганического происхождения, а именно фуллерен С60, наночастицы и ионы серебра Agnano, $\mathrm{Ag}+$, частицы оксида цинка $(\mathrm{ZnO})$. Современными инструментальными методами проведен анализ структурных, физических и антибактериальных свойств покрытий. Выводы: Анализ полученных результатов по синтезу и структурно-фазовых исследований апатит-биополимерных покрытий, полученных методом TSD в лаборатории «Бионанокомпозит» Сумского государственного университета в течение последних 5 лет предоставляет информацию о состоянии исследований по указанной проблематике и может быть полезным при дальнейших исследованиях ученых, в том числе молодых ученых.

Ключевые слова: покрытие, ортофосфаты кальция, биополимеры, термодепозиция 


\title{
HYBRID APATITE-BIOPOLYMER COATINGS OBTAINED BY THERMAL SUBSTRATE DEPOSITION METHOD ON MODEL IMPLANTS OF TITANIUM AND ITS ALLOYS
}

\author{
Leonid Sukhodub \\ sukhodub@yahoo.com \\ Dr.Sc.(Phys\&Math), \\ professor, corresponding \\ member of the National Academy \\ of Sciences of Ukraine \\ department of the biophysics, biochemistry, \\ pharmacology and biomolecular engineering \\ Sumy State University \\ Medical institute \\ Sumy, Ukraine
}

\begin{abstract}
Background -development and production of coatings for medical implants are a significant segment of the modern technology market. Given the number of patients who need surgery to restore the integrity of bone tissue, the amount of materials needed is estimated at tens of tons. Objective is to analyze the state of development and technologies of biomimetic production of multifunctional biocompatible nanostructured coatings based on calcium orthophosphates $(\mathrm{CaP})$ and natural biopolymers of chitosan $(\mathrm{CS})$, alginate $(\mathrm{Alg})$, collagen $(\mathrm{Cg})$ in the form of two-phase metal / coating systems. Method - the use of thermal deposition technology (TSD-temperature substrate deposition) from aqueous solutions of precursors. Results: This review summarizes the scientific data on methods for obtaining bioactive, antimicrobial $\mathrm{CaP}$ coatings and the study of their properties. Features of popular technologies are noted: plasma spraying, electrophoretic and electrochemical deposition, sol-gel, biomimetic deposition. Due to the increased resistance of microorganisms to a wide range of antibiotics in recent decades, as antimicrobial agents in the coatings were introduced alternative particles of inorganic origin, namely fullerene C60, nanoparticles of silver (Agnano) and silver ions $\left(\mathrm{Ag}^{+}\right)$, zinc oxide particles $(\mathrm{ZnO})$. The analysis of structural, physical and antibacterial properties of coatings is carried out by modern instrumental methods. Conclusions: Analysis of the results of the synthesis and structural-phase studies of apatite-biopolymer coatings obtained by TSD in the laboratory "Bionanocomposite" Sumy State University over the past 5 years provides information on the state of research on this issue and may be useful in further research by scientists. including young scientists.

Keywords: coatings, calcium orthophosphates, biopolymers, thermodeposition
\end{abstract}

